\title{
Determination of Trace Metals and Essential Minerals in Selected Fruit Juices in Minna, Nigeria
}

\author{
A. I. Ajai, S. S. Ochigbo, Z. Abdullahi, and P. I. Anigboro \\ Department of Chemistry, Federal University of Technology, Minna 920281, Nigeria \\ Correspondence should be addressed to A. I. Ajai; talk2alexajai@gmail.com
}

Received 18 February 2014; Revised 28 May 2014; Accepted 29 May 2014; Published 12 June 2014

Academic Editor: Haile Yancy

Copyright ( 2014 A. I. Ajai et al. This is an open access article distributed under the Creative Commons Attribution License, which permits unrestricted use, distribution, and reproduction in any medium, provided the original work is properly cited.

Levels of trace metals and essential minerals in selected fruit juice samples purchased from Minna were determined using atomic absorption spectrophotometer (AAS) and Flame photometer. From the obtained result, $\mathrm{Cu}, \mathrm{Fe}, \mathrm{Mn}, \mathrm{Na}$, and $\mathrm{Zn}$ were present in all the samples, while $\mathrm{Cd}, \mathrm{Pb}$, and $\mathrm{Cr}$ were not detectable in all the samples. Concentrations of $\mathrm{K}$ range between $1.31 \pm 0.10$ and $41.20 \pm 0.10 \mathrm{mg} / 100 \mathrm{~mL}, \mathrm{Na}$ between $15.47 \pm 0.15$ and $3.50 \pm 0.20 \mathrm{mg} / 100 \mathrm{~mL}, \mathrm{Mn}$ between $\mathrm{Nd}$ and $0.27 \pm 0.08 \mathrm{mg} / 100 \mathrm{~mL}$, Fe between Nd and $0.90 \pm 0.05 \mathrm{mg} / 100 \mathrm{~mL}$, Cu between Nd- $0.60 \pm 0.00 \mathrm{mg} / 100 \mathrm{~mL}$, and Zn between Nd- $0.09 \pm 0.01 \mathrm{mg} / 100 \mathrm{~mL}$, respectively. The trace metal levels in all the samples were within permissible limit as recommended by WHO for edible foods and drinks and could therefore be taken to compliment the deficiency of these essential minerals from other food sources.

\section{Introduction}

There has been an increasing trend in the production and consumption of local and imported fruit juices, both in the urban and rural areas of Nigeria and the world in general. The presence of impurities and foreign matter in finished products for human consumption is of great concern because they present health hazards when they exceed beneficial limits. The manufacture of juices requires special attention in terms of purity and the sources of water and its purification are crucial for maintaining quality and safety. Drinking water, fruit juices, and most drinks usually contain small amounts of essential trace elements, which contribute to dietary intakes, and the levels of these elements need to be continually monitored and controlled [1]. Some of these elements are important for the normal functions of the body but when their concentrations exceed an allowable limit [2], they cause acute and chronic poisoning leading to significant illness, reduced quality of life, and even death [3]. The presence of trace metals in water, juices, and different food substances and their health implications have been reported by other workers [4-9].
In a world faced with problem of food scarcity, fruits can act as very good sources of alternative nutrients to compliment the deficiency of these nutrients from other food sources, since they are known to be excellent sources of some essential minerals and vitamins and also contain carbohydrates in the form of soluble sugars, cellulose, and starch [10] and act as good sources of antioxidants [11-13].

In Nigeria, there exist different brands of fruit juices; some are manufactured by registered and recognized manufacturing companies and others by companies not recognized by the food and beverages regulatory agency in the country. Considering the importance of fruit juices to the growth and development of man, there is need to constantly monitor the quality of the product that is being sold to the consumer to ensure that their trace and essential minerals content are within the permissible level that will not be deleterious to health and so compliment the nutrient needs of man, thereby improving on the food security of the country. It is in line with these assertions that this study was set out to find out some trace metals and essential minerals content of some fruit juices sold in Minna metropolis. 


\section{Materials and Methods}

2.1. Precaution. To ensure reliability of the results, samples were carefully handled to avoid contamination. All glassware used was soaked in $1 \mathrm{M}$ nitric acid for $48 \mathrm{~h}$ and rinsed with ultrapure water. The reagents (nitric acid) were of analytical grades.

2.2. Samples Collection. 15 fruit juices bearing different brand names were purchased from various shops in Minna. They were grouped into three groups as follows:

Group 1: canned fruit juices made up of five brands;

Group 2: packaged fruit juices made up of five brands;

Group 3: Sachet fruit juices made up of five brands.

2.3. Digestion of Fruit Juices Samples. $10 \mathrm{~mL}$ of concentration nitric acid $\left(\mathrm{HNO}_{3}\right)$ was added to $5 \mathrm{~mL}$ of the fruit juice samples in a beaker and the solution was heated on a hot plate in a fume hood for 1 hour. This was then allowed to cool and filtered into a $50 \mathrm{~mL}$ volumetric flask and made up to $50 \mathrm{~mL}$ mark with distilled water and stored in a polyethylene container prior to analysis.

2.4. Analysis of Samples. The digested fruit juice samples were analysed for their trace metals and essential minerals using atomic absorption spectrophotometer (AAS) model 210/211 VGP Buck scientific at Ibadan, while $\mathrm{Na}$ and $\mathrm{K}$ were analysed using Flame photometer model Jenway PFP-7, UK.

2.5. Determination of the Efficiency of the Method. To determine the efficiency of the method, a recovery study was carried out. This was done by spiking a known concentration $(0.5 \mathrm{mg} / \mathrm{L})$ of one of the metals of interest into one of the juice samples prior to digestion and the sample was subjected to all the pretreatment steps as other samples and analysed using AAS after pretreatment and digestion. The percentage recovery was calculated using the following expression:

$$
\begin{aligned}
& \% \text { Recovery } \\
& =\frac{\text { Concentration obtained }(\mathrm{mg} / \mathrm{L})-\text { Concentration added }(\mathrm{mg} / \mathrm{L})}{\text { Concentration added }(\mathrm{mg} / \mathrm{L})} .
\end{aligned}
$$

\section{Results and Discussions}

Table 1 shows the result of the mean concentrations ( \pm standard deviation of trace metals and minerals in the different brands of canned fruit juices). They are represented by code name since the objective of the study was to obtain an overview of what was in the market at that point in time. The mean concentrations of sodium in the different canned juices ranged $212.70 \pm 0.15-276.70 \pm 0.15 \mathrm{mg} / \mathrm{L}$ with pineapple fruit juice sample having the highest concentration and mango fruit juice sample the lowest concentration, respectively. Other metals have concentrations ranging $58.80 \pm 0.07-194.00 \pm 0.20 \mathrm{mg} / \mathrm{L} \mathrm{K}, 1.20 \pm 0.02-9.00 \pm 0.05 \mathrm{mg} / \mathrm{L}$
Fe, $0.20 \pm 0.01-0.60 \pm 0.01 \mathrm{mg} / \mathrm{L} \mathrm{Cu}, 0.40 \pm 0.00-0.90 \pm$ $0.01 \mathrm{mg} / \mathrm{L} \mathrm{Zn}$, and $2.20 \pm 0.02-2.70 \pm 0.08 \mathrm{mg} / \mathrm{L} \mathrm{Mn}$, respectively, while $\mathrm{Pb}$ and $\mathrm{Cr}$ were not detected in all the canned fruit juices studied.

The concentration of $\mathrm{Fe}, \mathrm{Cu}$, and $\mathrm{Zn}$ in different canned fruit juices ranged 1. $20 \pm 0.02-9.00 \pm 0.05 \mathrm{mg} / \mathrm{L}, 0.20 \pm$ $0.01-0.60 \pm 0.01 \mathrm{mg} / \mathrm{L}$, and $0.40 \pm 0.01-0.90 \pm 0.01 \mathrm{mg} / \mathrm{L}$, respectively, with mango fruit juice having the highest concentration of Fe $(0.90 \pm 0.05 \mathrm{mg} / \mathrm{L})$ and $\mathrm{Zn}(0.90 \pm 0.01 \mathrm{mg} / \mathrm{L})$ and guava fruit juice having the highest concentration of $\mathrm{Cu}$ $(0.60 \pm 0.01 \mathrm{mg} / \mathrm{L})$. It should be noted that all these metals are commonly associated with plants or plant products. But most of the fruit juices do not contain $\mathrm{Mn}, \mathrm{Pb}$, and $\mathrm{Cr}$ indicating lack of chronic contaminants in the studied fruit juices.

Table 2 shows the concentration of trace metal and minerals in different packaged fruit juices analysed. The major minerals contained were $\mathrm{Na}$ and $\mathrm{K}$, with $\mathrm{Fe}, \mathrm{Cu}$, and $\mathrm{Zn}$ being present in some of the brands. The concentration of $\mathrm{Na}$ and $\mathrm{K}$ ranged between $154.70 \pm 0.15-335.00 \pm 0.20 \mathrm{mg} / \mathrm{L}$ and $54.50 \pm 0.10-412.00 \pm 0.10 \mathrm{mg} / \mathrm{L}$ with Ribena fruit juice sample having the least concentration of $\mathrm{Na}(154.70 \pm$ $0.15 \mathrm{mg} / \mathrm{L}$ ) and Soy good mango fruit juice sample having the highest $(335.00 \pm 0.20 \mathrm{mg} / \mathrm{L})$ and Happy Hour peach fruit juice having the least of $\mathrm{K}(54.50 \pm 0.10 \mathrm{mg} / \mathrm{L})$ and Five Alive Citrus Burst fruit juice having the highest $\mathrm{K}$ of $412.00 \pm 0.10 \mathrm{mg} / \mathrm{L}$, respectively.

Table 3 also shows the trace metal and minerals in different Sachets fruit juices studied. It also shows the presence of $\mathrm{Na}, \mathrm{K}, \mathrm{Fe}$, and $\mathrm{Cu}$ with $\mathrm{Na}$ and $\mathrm{K}$ having higher concentration ranging between $185.70 \pm 0.12-275.3 \pm 0.10 \mathrm{mg} / \mathrm{L} \mathrm{Na}$ in Chivita premium fruit juice and Vita vite multivitamin fruit juice and $13.10 \pm 0.10-56.10 \pm 0.07 \mathrm{mg} / \mathrm{L} \mathrm{K}$ in Fruit Maid pineapple fruit juice and Vita vite multivitamin fruit juice, respectively. Fe on the other hand ranged Nd-2.50 $\pm 0.10 \mathrm{mg} / \mathrm{L}$ Fe with Chivita premium fruit juice having the highest and Exotic chi orange peach nectar fruit juice the highest. However, $\mathrm{Cu}$ was present in trace amount in all the studied Sachet fruit juices and ranged $0.30 \pm 0.01-0.50 \pm 0.00 \mathrm{mg} / \mathrm{L}$, respectively.

The more toxic trace metals, $\mathrm{Mn}, \mathrm{Pb}$, and $\mathrm{Cr}$, were not detected in all the Sachet fruit juice studied indicating their suitability for consumption.

\section{Efficiency of the Method}

The efficiency of the method was determined by recovery study carried out using one of the samples by spiking by known amount of the metal of interest. From Table 1, for instance, $0.5 \mathrm{mg} / \mathrm{L}$ of copper was spiked into a sample of pineapple fruit juice and after pretreatment and analysis a concentration of $0.90 \mathrm{mg} / \mathrm{L}$ was obtained. Therefore, from the information, the percentage recovery for copper using the instrument is $80 \%$. This percentage recovery indicates that the instrument has the potential of giving an accurate result. According to European commission [14], recovery of 50$120 \%$ is an indication that a procedure adopted for an analysis is an acceptable procedure. 
TABLE 1: Trace metal and mineral content in different canned fruit juices (mg/L).

\begin{tabular}{lccccc}
\hline Metals/samples & Guava fruit juice & Pineapple fruit juice & Mango fruit juice & Apple fruit juice & Ginger fruit juice \\
\hline $\mathrm{Na}$ & $224.30 \pm 0.15^{\mathrm{b}}$ & $276.70 \pm 0.15^{\mathrm{e}}$ & $212.70 \pm 0.15^{\mathrm{a}}$ & $266.00 \pm 0.10^{\mathrm{d}}$ & $247.30 \pm 0.06^{\mathrm{c}}$ \\
$\mathrm{K}$ & $116.30 \pm 0.15^{\mathrm{b}}$ & $194.00 \pm 0.20^{\mathrm{d}}$ & $58.80 \pm 0.07^{\mathrm{a}}$ & $133.70 \pm 0.15^{\mathrm{c}}$ & $254.00 \pm 0.20^{\mathrm{e}}$ \\
$\mathrm{Fe}$ & $6.50 \pm 0.06^{\mathrm{d}}$ & $5.10 \pm 0.10^{\mathrm{c}}$ & $9.00 \pm 0.05^{\mathrm{e}}$ & $2.70 \pm 0.11^{\mathrm{b}}$ & $1.20 \pm 0.02^{\mathrm{a}}$ \\
$\mathrm{Cu}$ & $0.60 \pm 0.01^{\mathrm{c}}$ & $0.40 \pm 0.00^{\mathrm{b}}$ & $0.40 \pm 0.00^{\mathrm{b}}$ & $0.20 \pm 0.01^{\mathrm{a}}$ & $0.40 \pm 0.00^{\mathrm{b}}$ \\
$\mathrm{Zn}$ & $0.40 \pm 0.01^{\mathrm{a}}$ & $0.70 \pm 0.01^{\mathrm{c}}$ & $0.90 \pm 0.01^{\mathrm{d}}$ & $0.60 \pm 0.00^{\mathrm{bc}}$ & $0.50 \pm 0.01^{\mathrm{b}}$ \\
$\mathrm{Mn}$ & $0.00 \pm 0.00^{\mathrm{a}}$ & $2.20 \pm 0.02^{\mathrm{b}}$ & $0.00 \pm 0.00^{\mathrm{a}}$ & $0.00 \pm 0.00^{\mathrm{a}}$ & $2.70 \pm 0.08^{\mathrm{b}}$ \\
$\mathrm{Pb}$ & $\mathrm{Nd}$ & $\mathrm{Nd}$ & $\mathrm{Nd}$ & $\mathrm{Nd}$ & $\mathrm{Nd}$ \\
$\mathrm{Cd}$ & $\mathrm{Nd}$ & $\mathrm{Nd}$ & $\mathrm{Nd}$ & $\mathrm{Nd}$ & $\mathrm{Nd}$ \\
$\mathrm{Cr}$ & $\mathrm{Nd}$ & $\mathrm{Nd}$ & $\mathrm{Nd}$ & $\mathrm{Nd}$ \\
\hline
\end{tabular}

Those with different superscripts across rows for each brand of fruit juices are significantly different from each other $(P<0.05)$, where a $<$ b $<<$ d $<$ e. Key: Nd: not detected.

TABLE 2: Trace metal and mineral content in different packaged fruit juices (mg/L).

\begin{tabular}{|c|c|c|c|c|c|}
\hline Metals/samples & $\begin{array}{l}\text { Five Alive Citrus } \\
\text { Burst fruit juice }\end{array}$ & $\begin{array}{l}\text { Happy Hour peach } \\
\text { fruit juice }\end{array}$ & $\begin{array}{c}\text { Soy good } \\
\text { mango fruit juice }\end{array}$ & $\begin{array}{l}\text { Passion fruit } \\
\text { juice }\end{array}$ & $\begin{array}{c}\text { Ribena fruit } \\
\text { juice }\end{array}$ \\
\hline $\mathrm{Na}$ & $201.70 \pm 0.12^{\mathrm{b}}$ & $234.00 \pm 0.01^{\mathrm{c}}$ & $335.00 \pm 0.20^{\mathrm{e}}$ & $246.70 \pm 0.15^{\mathrm{d}}$ & $154.70 \pm 0.15^{\mathrm{a}}$ \\
\hline $\mathrm{K}$ & $412.00 \pm 0.10^{\mathrm{e}}$ & $54.50 \pm 0.10^{\mathrm{a}}$ & $191.80 \pm 0.09^{\mathrm{d}}$ & $188.60 \pm 0.14^{c}$ & $81.30 \pm 0.09^{b}$ \\
\hline $\mathrm{Fe}$ & $1.10 \pm 0.04^{\mathrm{b}}$ & $0.00 \pm 0.00^{\mathrm{a}}$ & $0.00 \pm 0.00^{\mathrm{a}}$ & $1.80 \pm 0.03^{c}$ & $0.80 \pm 0.02^{\mathrm{b}}$ \\
\hline $\mathrm{Cu}$ & $0.00 \pm 0.00^{\mathrm{a}}$ & $0.50 \pm 0.01^{\mathrm{c}}$ & $0.00 \pm 0.00^{\mathrm{a}}$ & $0.00 \pm 0.00^{\mathrm{a}}$ & $0.30 \pm 0.01^{\mathrm{b}}$ \\
\hline $\mathrm{Zn}$ & $0.30 \pm 0.01^{\mathrm{bc}}$ & $0.40 \pm 0.01^{\mathrm{c}}$ & $0.30 \pm 0.01^{\mathrm{b}}$ & $0.00 \pm 0.00^{\mathrm{a}}$ & $0.00 \pm 0.00^{\mathrm{a}}$ \\
\hline $\mathrm{Mn}$ & $\mathrm{Nd}$ & $\mathrm{Nd}$ & $\mathrm{Nd}$ & $\mathrm{Nd}$ & $\mathrm{Nd}$ \\
\hline $\mathrm{Pb}$ & $\mathrm{Nd}$ & $\mathrm{Nd}$ & $\mathrm{Nd}$ & $\mathrm{Nd}$ & $\mathrm{Nd}$ \\
\hline $\mathrm{Cd}$ & $\mathrm{Nd}$ & $\mathrm{Nd}$ & $\mathrm{Nd}$ & $\mathrm{Nd}$ & $\mathrm{Nd}$ \\
\hline $\mathrm{Cr}$ & $\mathrm{Nd}$ & $\mathrm{Nd}$ & $\mathrm{Nd}$ & $\mathrm{Nd}$ & $\mathrm{Nd}$ \\
\hline
\end{tabular}

Those with different superscripts across rows for each brand of fruit juices are significantly different from each other $(P<0.05)$, where a b $<\mathrm{c}<\mathrm{d}<\mathrm{e}$. Key: Nd: not detected.

\section{Discussion}

The concentrations of $\mathrm{Fe}, \mathrm{Cu}$, and $\mathrm{Zn}$ are very low or completely not detected in some of the studied fruit juices (Table 1). This variation can be attributed to the packaging materials used, while the presence of these metal ions in canned fruit juices in Table 1 can be attributed to the leaching of the canned containers used by the acidic medium of the juices since some of these canned materials are made with these metals such as $\mathrm{Zn}$ and Fe.

Manganese which ranged $0.00-2.70 \pm 0.08 \mathrm{mg} / \mathrm{L}$ in this study is essential metal and a potent neurotoxin. Manganese accumulates in mitochondria and acts as a major source of superoxide, which can oxidize $\mathrm{Mn}^{2+}$ to the powerful oxidizing agents $\mathrm{Mn}^{3+}$. Oxidation of important cell components by $\mathrm{Mn}^{3+}$ has been reported as the cause of toxic effect of manganese [15].

Maduabuchi et al. [16] reported cadmium levels of $0.003-0.081 \mathrm{mg} / \mathrm{L}$ in canned drinks and $0.006-0.071 \mathrm{mg} / \mathrm{L}$ in noncanned drinks and lead levels of $0.002-0.0073 \mathrm{mg} / \mathrm{L}$ in canned drinks and $0.092 \mathrm{mg} / \mathrm{L}$ in noncanned drinks, respectively, while in this study no lead or cadmium was detected in canned, packaged, and Sachet fruit juices.
Krejpcio et al. [17] reported lead, cadmium, copper, and zinc levels of $0.020-0.46 \mathrm{mg} / \mathrm{L}, 0.004-0.060 \mathrm{mg} / \mathrm{L}, 0.047-$ $1.840 \mathrm{mg} / \mathrm{L}$, and $0.063-3.39 \mathrm{mg} / \mathrm{L}$, respectively, in canned and noncanned drinks. Cadmium and lead were not detected in this work.

Generally, in the canned and packaged fruit juice, $\mathrm{Cd}, \mathrm{Pb}$, and $\mathrm{Cr}$ were not detected indicating nontoxicity of the fruit juices and the suitability of the juices for consumption since some of these metals have been reported to be toxic when present in food even in very minute amount. Comparing the essential mineral content in the various canned fruit juices of Nd-27.67 $\pm 0.15 \mathrm{mg} / \mathrm{L}$ with that reported by Iwegbue et al. [18], of between $0.45-4.00 \mathrm{mg} / \mathrm{L} \mathrm{Zn}$ and $0.37-$ $45.54 \mathrm{mg} / \mathrm{L} \mathrm{Fe}$ in mango and apple fruit juices samples collected from Agbor and Warri of Delta state Nigeria, there is a correlation between some of the parameters. Despite the low amount of some of these essential minerals in the studied fruit juices, they can still compliment the deficiency of these minerals in the human diet from other food sources when consumed thereby, helping to improve on the nutritional needs of the individual. The variation between the two studies could be attributed to types of samples, production method and experimental error. Generally, the level of more toxic 
TABLE 3: Trace metal and mineral content in different Sachet fruit juices (mg/L).

\begin{tabular}{lccccc}
\hline Metals/samples & $\begin{array}{c}\text { Chivita premium } \\
\text { fruit juice }\end{array}$ & $\begin{array}{c}\text { Exotic chi orange } \\
\text { peach } \\
\text { Nectar fruit juice }\end{array}$ & $\begin{array}{c}\text { Fruit maid } \\
\text { pineapple fruit } \\
\text { juice }\end{array}$ & $\begin{array}{c}\text { Vitavite } \\
\text { multivitamin } \\
\text { fruit juice }\end{array}$ & $\begin{array}{c}\text { California } \\
\text { pineapple } \\
\text { fruit juice }\end{array}$ \\
\hline $\mathrm{Na}$ & $185.70 \pm 0.12^{\mathrm{a}}$ & $247.30 \pm 0.12^{\mathrm{c}}$ & $234.30 \pm 0.06^{\mathrm{b}}$ & $275.30 \pm 0.10^{\mathrm{e}}$ & $253.00 \pm 0.06^{\mathrm{d}}$ \\
$\mathrm{K}$ & $43.30 \pm 0.06^{\mathrm{c}}$ & $46.70 \pm 0.15^{\mathrm{d}}$ & $13.10 \pm 0.10^{\mathrm{a}}$ & $56.10 \pm 0.07^{\mathrm{e}}$ & $36.80 \pm 0.08^{\mathrm{b}}$ \\
$\mathrm{Fe}$ & $\mathrm{Nd}$ & $2.50 \pm 0.10^{\mathrm{c}}$ & $1.90 \pm 0.17^{\mathrm{a}}$ & $2.40 \pm 0.02^{\mathrm{b}}$ & $2.50 \pm 0.05^{\mathrm{c}}$ \\
$\mathrm{Cu}$ & $0.30 \pm 0.01^{\mathrm{a}}$ & $0.30 \pm 0.02^{\mathrm{a}}$ & $0.30 \pm 0.01^{\mathrm{a}}$ & $0.30 \pm 0.01^{\mathrm{a}}$ & $0.50 \pm 0.00^{\mathrm{b}}$ \\
$\mathrm{Zn}$ & $\mathrm{Nd}$ & $\mathrm{Nd}$ & $\mathrm{Nd}$ & $0.80 \pm 0.01$ & $\mathrm{Nd}$ \\
$\mathrm{Mn}$ & $\mathrm{Nd}$ & $\mathrm{Nd}$ & $\mathrm{Nd}$ & $\mathrm{Nd}$ & $\mathrm{Nd}$ \\
$\mathrm{Pb}$ & $\mathrm{Nd}$ & $\mathrm{Nd}$ & $\mathrm{Nd}$ & $\mathrm{Nd}$ & $\mathrm{Nd}$ \\
$\mathrm{Nd}$ & $\mathrm{Nd}$ & $\mathrm{Nd}$ & $\mathrm{Nd}$ & $\mathrm{Nd}$ & $\mathrm{Nd}$ \\
$\mathrm{Cr}$ & $\mathrm{Nd}$ & $\mathrm{Nd}$ & $\mathrm{Nd}$ & $\mathrm{Nd}$ \\
\hline
\end{tabular}

Those with different superscripts across rows for each brand of fruit juices are significantly different from each other $(P<0.05)$ where $\mathrm{a}<\mathrm{b}<\mathrm{c}<\mathrm{d}<\mathrm{e}$; Key: $\mathrm{Nd}=$ Not detected.

trace metals $(\mathrm{Pb}, \mathrm{Cd}$, and $\mathrm{Cr})$ was not detected or below detectable limit in all the samples analyzed suggesting that the fruit juices are safe for human consumption indicating that they were within the permissible limit that is nondeleterious to health as recommended by WHO [19] for drinking water.

The results of the statistical analysis of different canned fruit juices are studied using Duncan multirange test and oneway ANOVA at 95\% confidence level. Table 1 shows cluster of results with no specific brand of canned fruit juice having the highest or lowest of the metal ion analysed. The superscript indicates the differences or similarity between various brands. Those with different superscripts across rows for each brand of fruit juices are significantly different from each other $(P<$ $0.05)$, where $\mathrm{a}<\mathrm{b}<\mathrm{c}<\mathrm{d}<\mathrm{e}$.

Similarly, clusters of result were obtained from the statistical analysis of the different Sachet fruit juices (Table 2) with no specific brand having the highest burden of the metal ions with the exception of Vitavite multivitamin fruit juice with highest concentration of $\mathrm{Na}$ and $\mathrm{K}$.

Generally, the variation in the statistical result with no particular brand having an overriding property over others is due basically to the different processing method adopted and the various additives added by each manufacturer which brought about change in the concentration of the various metal ions in the studied samples.

\section{Conclusion}

From the results of this study, it can be stated that the studied fruit juices are free of toxic trace metals and the mineral content is within the limit that will not be harmful to the consumer and the studied fruit juices are suitable for consumption in order to compliment the deficiency of the essential minerals from other food sources and improve on the overall nutritional needs of the consumer. We also recommend that those manufacturers using can materials for packaging their juices should ensure that they are well lacquered before use to avert leaching of the toxic materials of the can into the juice.

\section{Conflict of Interests}

The correspondence author on behalf of other coauthors declares that there is no conflict of interests regarding the publication of this paper.

\section{References}

[1] A. Ikem, S. Odueyungbo, N. O. Egiebor, and K. Nyavor, "Chemical quality of bottled waters from three cities in eastern Alabama," Science of the Total Environment, vol. 285, no. 1-3, pp. 165-175, 2002.

[2] World Health Organization, WHO Guidelines For Drinking Water Quality, vol. 2, World Health Organization, Geneva, Switzerland, 2nd edition, 1996.

[3] A. S. Prasad, Trace Elements in Human Health and Disease. Vol II, Academic Press, New York, NY, USA, 1976.

[4] M. F. Bouchard, S. Sauvé, B. Barbeau et al., "Intellectual impairment in school-age children exposed to manganese from drinking water," Environmental Health Perspectives, vol. 119, no. 1, pp. 138-143, 2011.

[5] L. L. Bergeson, "The proposed lead NAAQS: is consideration of cost in the clean air act's future?" Environmental Quality Management, vol. 18, no. 1, pp. 79-83, 2008.

[6] M. S. Golub, Ed., "Summary" Metals, Fertility, and Reproductive Toxicity, Taylor and Francis, Boca Raton, Fla, USA, 2005.

[7] M. Glei, S. Klenow, J. Sauer, U. Wegewitz, K. Richter, and B. L. Pool-Zobel, "Hemoglobin and hemin induce DNA damage in human colon tumor cells HT29 clone 19A and in primary human colonocytes," Mutation Research, vol. 594, no. 1-2, pp. 162-171, 2006.

[8] P. Senesse, S. Méance, V. Cottet, J. Faivre, and M.-C. BoutronRuault, "High dietary iron and copper and risk of colorectal cancer: a case-control study in Burgundy, France," Nutrition and Cancer, vol. 49, no. 1, pp. 66-71, 2004.

[9] D. A. Eastmond, J. T. MacGregor, and R. S. Slesinski, "Trivalent chromium: assessing the genotoxic risk of an essential trace element and widely used human and animal nutritional supplement," Critical Reviews in Toxicology, vol. 38, no. 3, pp. 173-190, 2008. 
[10] N. Nahar, S. Rahman, and M. Mosiihuzzaman, "Analysis of carbohydrates in seven edible fruits of Bangladesh," Journal of the Science of Food and Agriculture, vol. 51, pp. 185-192, 1990.

[11] E. M. Kurowska, J. D. Spence, J. Jordan et al., "HDL-cholesterolraising effect of orange juice in subjects with hypercholesterolemia," The American Journal of Clinical Nutrition, vol. 72, no. 5, pp. 1095-1100, 2000.

[12] L. B. Frank, L. S. Matza, D. A. Revicki, and J. Y. Chung, "Depression and health-related quality of life for low-income African-American women in the U.S," Quality of Life Research, vol. 14, no. 10, pp. 2293-2301, 2005.

[13] W. M. El-Ghanim, L. M. Hassan, T. M. Galal, and A. Badr, "Floristic composition and vegetation analysis in Hail region north of central Saudi Arabia," Saudi Journal of Biological Sciences, vol. 17, no. 2, pp. 119-128, 2010.

[14] European Commission, "Commission Recommendation No. 2005/108 of 4 February 2005 on the further investigation into the levels of polycyclic aromatic hydrocarbons in certain foods," Official Journal of the European Union, vol. 34, pp. 3-5, 2005.

[15] T. E. Gunter, L. M. Miller, C. E. Gavin et al., "Determination of the oxidation states of manganese in brain, liver, and heart mitochondria," Journal of Neurochemistry, vol. 88, no. 2, pp. 266-280, 2004.

[16] J.-M. U. Maduabuchi, E. O. Adigba, C. N. Nzegwu, C. I. Oragwu, I. P. Okonkwo, and O. E. Orisakwe, "Arsenic and chromium in canned and non-canned beverages in Nigeria: a potential public health concern," International Journal of Environmental Research and Public Health, vol. 4, no. 1, pp. 28-33, 2007.

[17] Z. Krejpcio, S. Sionkowski, and J. Bartela, "Safety of fresh fruits and juices available on the Polish market as determined by heavy metal residues," Polish Journal of Environmental Studies, vol. 14, no. 6, pp. 877-881, 2005.

[18] C. M. A. Iwegbue, S. O. Nwozo, E. K. Ossai, and G. E. Nwajei, "Heavy metal composition of some imported canned fruit drinks in Nigeria," The American Journal of Food Technology, vol. 3, no. 3, pp. 220-223, 2008.

[19] WHO, Guidelines For Drinking Water Quality, World Health Organization, Geneva, Switzerland, 2008. 

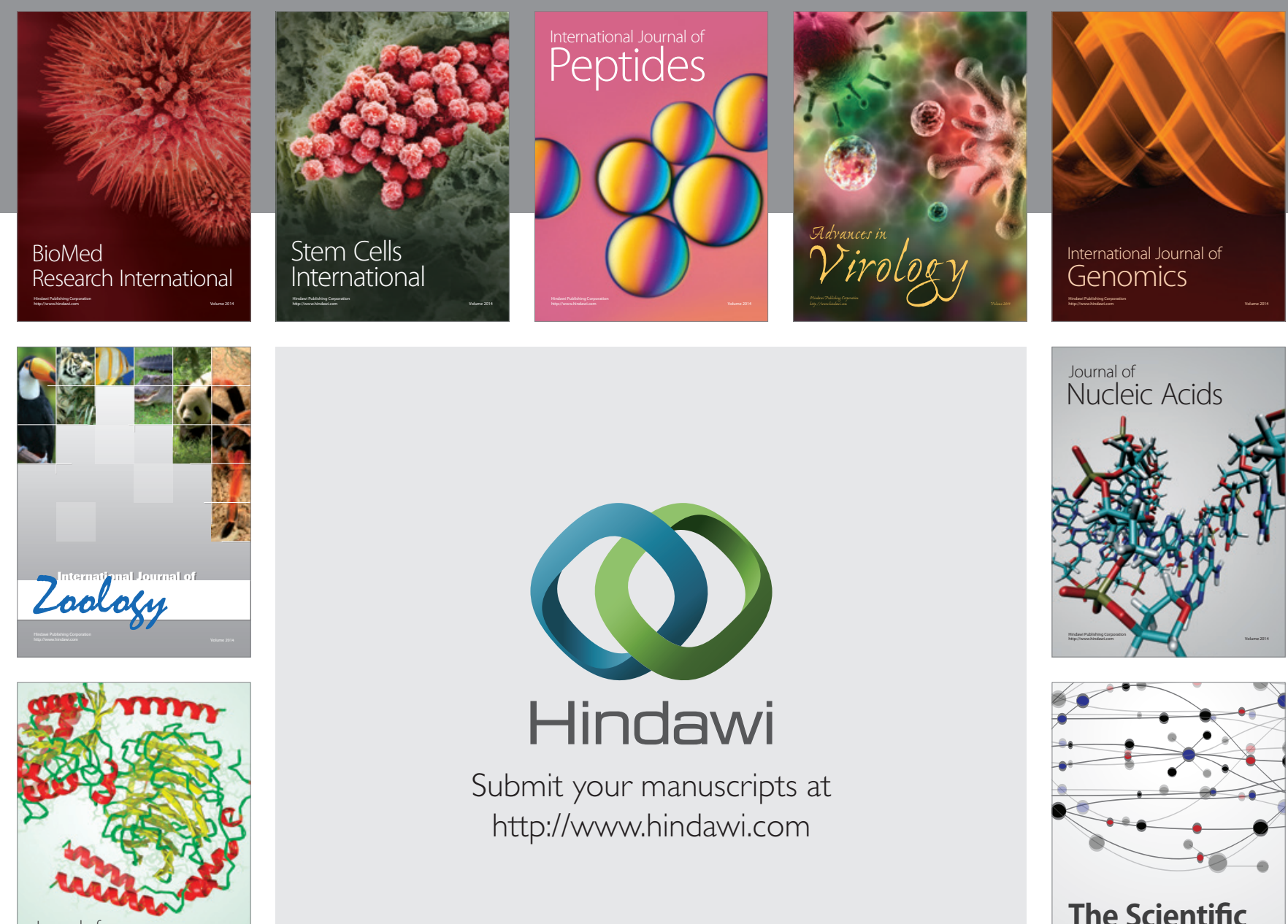

Submit your manuscripts at

http://www.hindawi.com

Journal of
Signal Transduction
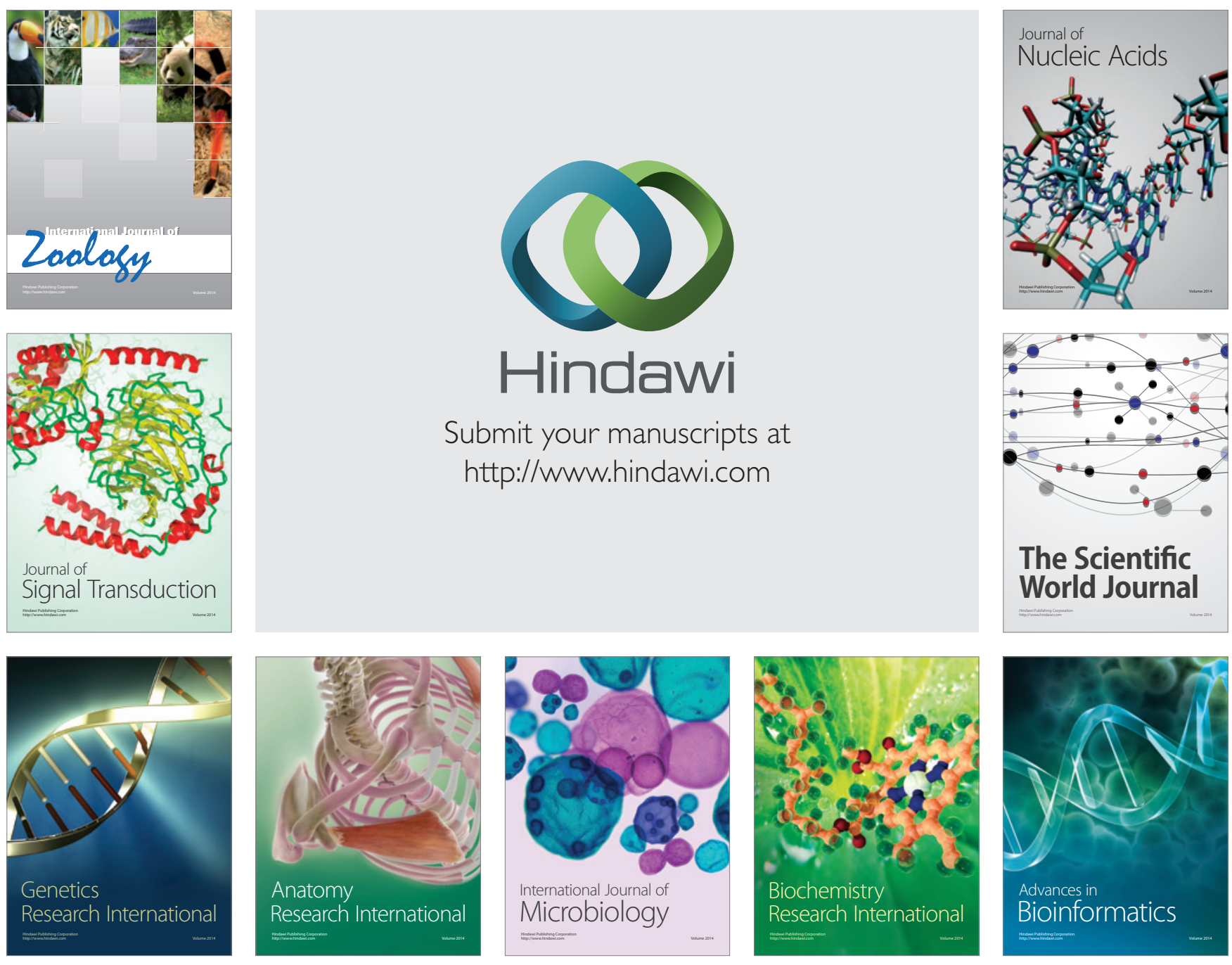

The Scientific World Journal
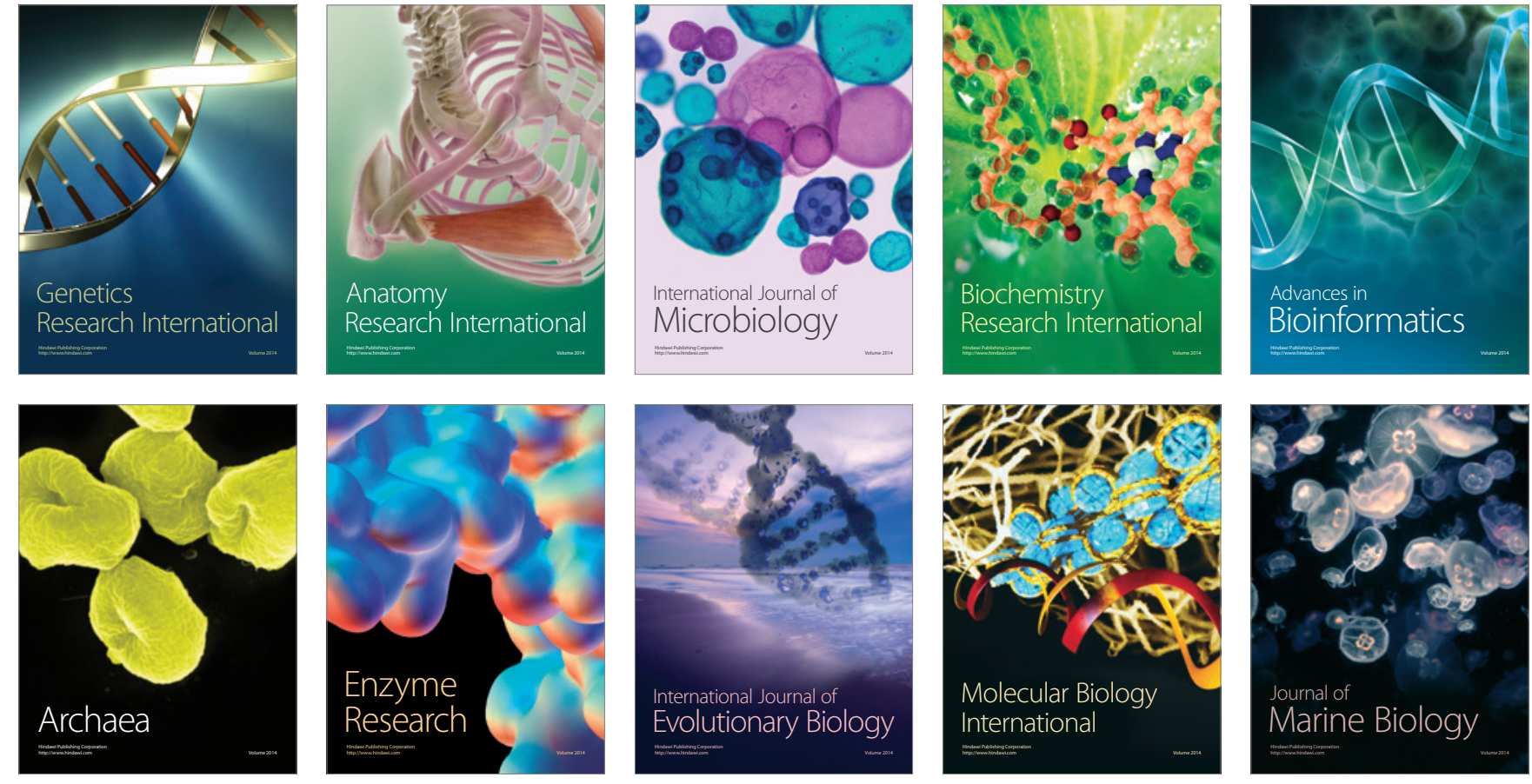